\title{
Sociology by Teachers, Senior Students and Professional Master Students for Teaching
}

\author{
MA/MSc Aida Serjanaj \\ National Agency of Exams \\ aidaserjanaj@gmail.com
}

\begin{abstract}
This research is about the role of sociology according to literature, my experience and a questionnaire. The result about it is that the majority of the respondent's estimate about sociology. The answers are connected mostly with the impact of sociological knowledge in making them more courageous in certain situations, defining their individual characteristics, seeing what type of individual they are, discovering new things that they wish and possibly use them, analyzing all the phases of the personal development, making them more optimistic, braver, and more communicative in many aspects, knowing themselves better and make a challenge to it, knowing your best friend better, creating a new concept on them, their character and behavior, you know yourself better, life experience has learned me much more; learning by doing, learning from mistakes, learning different cultures of living, etc. Study sociology is very important. It must be a compulsory subject at our pre-university curriculum.
\end{abstract}

Keywords: sociology, value, personal development

\section{Methodology}

Study of literature; Participating Survey; Questionnaire

\section{Study of literature}

Sociology is the study of human social life. Human social life is complex and encompasses many facets of the human experience. Because of its complexity, the discipline of sociology has been subdivided over time into specialty areas ${ }^{1}$. Sociology can perhaps be best regarded as an attempt to name that which secretely keeps society going ( Whitty and Young, 1976).

One of its basic concepts is culture. It consists of the beliefs, behaviors, objects, and other characteristics common to the members of a particular group or society. Through culture, people and groups define themselves, conform to society's shared values, and contribute to society. Thus, culture includes many societal aspects: language, customs, values, norms, mores, rules, tools, technologies, products, organizations, and institutions. ${ }^{2}$ That's why the study of sociology is very important. It is the process by which humans learn how to function in a particular society. Another basic concept of sociology is socialization. Although it is observably essential among humans, it is important to note here that socialization is very much culturally-relative, meaning that the process and outcomes do vary from culture to culture. Sociology extends its object of study anywhere people find themselves. It is connected with:

Social Life, such as Society, Culture, Socialization, Groups

${ }^{1}$ www.cliffsnotes.com/.../Culture-and-Society-Defined.topicArticleld-...

${ }^{2}$ Sociology of Education 
Social Inequality, such as Stratification, Race and Ethnicity, Gender

Social Institutions, such as Economy, Family, Religion, etc.

Arnett ${ }^{1}$ in presenting a new theoretical understanding of socialization, outlined what he believes to be the three goals of socialization:

impulse control and the development of a conscience role preparation and performance, including occupational roles, gender roles, and roles in institutions such as marriage and parenthood the cultivation of sources of meaning, or what is important, valued, and to be lived for.

In short, socialization is the process that prepares humans to function in social life. It should be re-iterated here that socialization is culturally relative - people in different cultures and people that occupy different racial, classed, gendered, sexual, and religious social locations are socialized differently.

Studying issues such it becomes necessary for study in schools. In existing pre-university curriculum, it is an optional subject in our schools. At the core curriculum subjects such place that retrieve information from 2-3 times during high school, such as: training for life, citizenship, biology, etc ${ }^{2}$. Sociology provides information on social problems. Its impact on civic participation is very large. Sociology gives information on social issues. Its effect on an active citizenly participation is very important. We need the sociology of education. It is the study of how public institutions and individual experiences affect education and its outcomes. It is mostly concerned with the public schooling systems of modern industrial societies, including the expansion of higher, further, adult, and continuing education. ${ }^{3}$

\section{Participating Survey}

Being a teacher of sociology for 20 years among high school students has helped me to watch and study:

Change in their behavior from their first year of high school to the last one

Their indifference towards disturbing issues in community at the beginning of the high school

Their active participation to effect the others;

This is completed through: educative classes, different activities, regular relations with social groups in need such as orphanages, asylums, competitions between classes and schools, having a continuous communication with colleagues of other schools from different regions of Albania, training sessions for our curricula which are always in process of changing, training sessions for the standards of learning, training sessions for the standards of teachers of social studies school subjects.

All these activities have been useful for a continuous exchange of experiences on how better it could be the education of the youth who lack the necessities of a normal life.

\section{Questionnaire}

There were asked 91 senior students, 70 teachers, and 239 professional master students for teaching subjects such as sociology, literature, math, history and geography. $82 \%$ of the questioned people were females and $18 \%$ were males. 


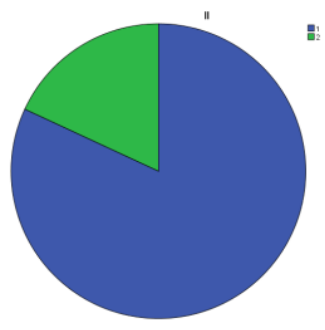

Question number 1:

They were asked to choose three of these values they esteemed the most.

\begin{tabular}{|l|l|}
\hline 1 & Wealthiness \\
\hline 2 & Personal dignity \\
\hline 3 & Patriotism \\
\hline 4 & Tolerance \\
\hline 5 & Education \\
\hline 6 & Humanism \\
\hline 7 & Competitive spirit \\
\hline 8 & Practical spirit \\
\hline 9 & Respect for outstanding individuals \\
\hline 10 & Innovatory spirit \\
\hline 11 & Sincerity \\
\hline 12 & Pragmatic spirit \\
\hline 13 & Honesty \\
\hline 14 & Correctness \\
\hline 0 & Others (write:............... \\
\hline 999 & Without answer \\
\hline
\end{tabular}

The following table shows the frequency of each chosen value listed on the table. It shows the percentage for each one and its accumulative percentage. (this is for professional master students)

\begin{tabular}{|c|c|c|c|c|c|}
\hline & & Frequency & Percentage & Valid Percentage & $\begin{array}{l}\text { Cumulative } \\
\text { Percentage }\end{array}$ \\
\hline \multirow[t]{15}{*}{ Valid } & 1 & 7 & 2.9 & 2.9 & 2.9 \\
\hline & 2 & 42 & 17.6 & 17.6 & 20.5 \\
\hline & 3 & 11 & 4.6 & 4.6 & 25.1 \\
\hline & 4 & 10 & 4.2 & 4.2 & 29.3 \\
\hline & 5 & 75 & 31.4 & 31.4 & 60.7 \\
\hline & 6 & 29 & 12.1 & 12.1 & 72.8 \\
\hline & 7 & 3 & 1.3 & 1.3 & 74.1 \\
\hline & 8 & 2 & .8 & .8 & 74.9 \\
\hline & 9 & 1 & 4 & .4 & 75.3 \\
\hline & 10 & 3 & 1.3 & 1.3 & 76.6 \\
\hline & 11 & 15 & 6.3 & 6.3 & 82.8 \\
\hline & 12 & 4 & 1.7 & 1.7 & 84.5 \\
\hline & 13 & 31 & 13.0 & 13.0 & 97.5 \\
\hline & 14 & 6 & 2.5 & 2.5 & 100.0 \\
\hline & Total & 239 & 100.0 & 100.0 & \\
\hline
\end{tabular}


It results that education has the biggest frequency chosen by the questioned people as the most precious value. It is the same result for the teachers and the senior students, too.

The second with the biggest frequency is chosen Personal Dignity. ( the $2^{\text {nd }}$ listed on the table)

The $3^{\text {rd }}$ with the biggest frequency chosen is Correctness. (the $14^{\text {th }}$ listed on the table)

Question number 2:

In evaluating the knowledge which helps them in knowing better themselves, 118 of them have answered that knowledge on sociology has helped them; 84 of them think on artistic literature.

There are almost the same results for teachers and senior students.

Some of the explanations on how and why this knowledge has helped them are:

It has made me more courageous in certain situations

In defining my individual characteristics

Seeing what type of individual I am

Knowing my aggressive temperament

Discovering new things that I wish I had in my real life and possibly use them

Analyzing all the phases of my personal development since I was a child

Making me more optimistic, braver, and more communicative in many aspects

Knowing sociology better, we know ourselves better and make a challenge to it

Knowing your best friend better, we know ourselves better at the same time

Putting myself in different book's situations

Finding myself in different characters of literature

Creating a new concept on me, my character and my behavior

Taking much more knowledge useful for daily life

Learning something new, you know yourself better

Life experience has learned me much more; learning by doing, learning from mistakes

Learning different cultures of living

Setting yourself in different situations

Learning about behaviors we learn who we are and what we do

Categorizing myself helps me in my daily behavior 
Being more tolerant; having an easier communication

Defining my own character

Learning individual's different socio-psychological characteristics

Knowing the past of the peoples and their cultures we can make conclusions for their special attributes

Studying man's life and all his problems through life, I can understand my advantages

Being a respectable member of the society, makes me understand how important is to me as a member of this society that surround me

Reading topics on cultures and behaviors, we learn how to be more conscientious

Systematizing my sociologic knowledge, I can see better the differences between me and other people

Thinking how I would act as I were the character of the book, I understand how I am;

Question number 3:

\begin{tabular}{|l|l|l|l|l|l|}
\hline \multicolumn{2}{|c|}{} & Frequency & $\begin{array}{l}\text { Percentag } \\
\text { e }\end{array}$ & $\begin{array}{l}\text { Valid } \\
\text { Percentag } \\
\text { e }\end{array}$ & $\begin{array}{l}\text { Cumulative } \\
\text { Percentag } \\
\text { e }\end{array}$ \\
\hline \multirow{6}{*}{} & Frequency & Percent & $\begin{array}{l}\text { Valid } \\
\text { Percent }\end{array}$ & $\begin{array}{l}\text { Cumulative } \\
\text { Percent }\end{array}$ \\
\hline \multirow{4}{*}{ Valid } & 1 & 118 & 49.4 & 49.6 & 49.6 \\
\cline { 2 - 6 } & 2 & 84 & 35.1 & 35.3 & 84.9 \\
\cline { 2 - 6 } & 3 & 35 & 14.6 & 14.7 & 99.6 \\
\cline { 2 - 6 } & 999 & 1 & .4 & .4 & 100.0 \\
\cline { 2 - 6 } & Total & 238 & 99.6 & 100.0 & \\
\hline Missing & System & 1 & .4 & & \\
\hline
\end{tabular}

Analyzing the number of sociologic books read during last 5 five years, results that:

\begin{tabular}{|c|c|c|c|c|c|}
\hline & & Frequency & Percentage & $\begin{array}{l}\text { Valid } \\
\text { Percentage }\end{array}$ & $\begin{array}{l}\text { Cumulative } \\
\text { Percentage }\end{array}$ \\
\hline \multirow[t]{12}{*}{ Valid } & 0 & 116 & 48.5 & 50.9 & 50.9 \\
\hline & 1 & 32 & 13.4 & 14.0 & 64.9 \\
\hline & 2 & 29 & 12.1 & 12.7 & 77.6 \\
\hline & 3 & 8 & 3.3 & 3.5 & 81.1 \\
\hline & 4 & 11 & 4.6 & 4.8 & 86.0 \\
\hline & 5 & 6 & 2.5 & 2.6 & 88.6 \\
\hline & 6 & 4 & 1.7 & 1.8 & 90.4 \\
\hline & 7 & 4 & 1.7 & 1.8 & 92.1 \\
\hline & 8 & 2 & 8 & .9 & 93.0 \\
\hline & 9 & 1 & 4 & 4 & 93.4 \\
\hline & 10 & 15 & 6.3 & 6.6 & 100.0 \\
\hline & Total & 228 & 95.4 & 100.0 & \\
\hline Missing & System & 11 & 4.6 & & \\
\hline \multicolumn{2}{|l|}{ Total } & 239 & 100.0 & & \\
\hline & & & & & \\
\hline
\end{tabular}


From 239 students of professional master in teaching profile, 116 of them haven't read any sociologic book; 6 of them have read 5 books, and 15 of them have read

\begin{tabular}{|c|c|c|c|c|c|}
\hline & & Frequency & Percentage & $\begin{array}{l}\text { Valid } \\
\text { Percentage }\end{array}$ & $\begin{array}{l}\text { Cumulative } \\
\text { Percentage }\end{array}$ \\
\hline \multirow[t]{12}{*}{ Valid } & 0 & 56 & 23.4 & 23.8 & 23.8 \\
\hline & 1 & 6 & 2.5 & 2.6 & 26.4 \\
\hline & 2 & 7 & 2.9 & 3.0 & 29.4 \\
\hline & 3 & 6 & 2.5 & 2.6 & 31.9 \\
\hline & 4 & 13 & 5.4 & 5.5 & 37.4 \\
\hline & 5 & 14 & 5.9 & 6.0 & 43.4 \\
\hline & 6 & 7 & 2.9 & 3.0 & 46.4 \\
\hline & 7 & 10 & 4.2 & 4.3 & 50.6 \\
\hline & 8 & 4 & 1.7 & 1.7 & 52.3 \\
\hline & 9 & 10 & 4.2 & 4.3 & 56.6 \\
\hline & 10 & 102 & 42.7 & 43.4 & 100.0 \\
\hline & Total & 235 & 98.3 & 100.0 & \\
\hline Missing & System & 4 & 1.7 & & \\
\hline \multicolumn{2}{|l|}{ Total } & 239 & 100.0 & & \\
\hline
\end{tabular}

10 books.

Analyzing the number of artistic books read during last 5 five years, results that:

Form 239 students of professional master in teaching profile, 56 of them haven't read any sociologic books; 14 of them have read 5 books, and 102 of them have read 10 books.

From 70 teachers, 12 of them haven't read any sociologic book; 11 others have read 3-5 books; 47 of them have read 510 books.

From 91senior students, 49 of them haven't read any sociologic book; 18 others have read 3-5 books; 24 of them have read 5-10 books.

This is a situation we have to do a lot for sociology and the students.

\section{Conclussions and recomandations:}

Study sociology is very important.

Sociology helps personal development.

Sociology must be a compulsory subject at our pre-university curriculum. 


\section{Bibliography}

Arnett, Jeffrey J. 1995. Broad and Narrow Socialization: The Family in the Context of a Cultural Theory. Journal of Marriage and the Family 57( 3):617-28. 1

Gordon Marshall (ed) A Dictionary of Sociology (Article: Sociology of Education), Oxford University Press, 1998

https://en. wikipedia. org/wiki/Sociology_of_education

http://en. wikibooks. org/wiki/introduction to sociology

www. mas. gov. al

www. izha. edu. al 